\title{
ANALISIS PLAGIARISME LOGO OLEH INKOM TEHSNAB
}

\author{
Edo Galasro Limbong*1, Siti Amalia ${ }^{2}$, Ibnu Fadhila ${ }^{3}$ \\ Universitas Indraprasta PGRI Jakarta \\ *corresponding author: Edo Galasro Limbong, edogalasro limbong@yahoo.co.id, Jakarta, Indonesia
}

\begin{abstract}
Abstrak. Adanya internet banyak dampak yang ditimbulkan, salah satunya adalah dampak negatif. Dalam industri desain komunikasi visual sangat memungkin hal tersebut terjadi, karena sangat berperan penting dalam proses pencarian ide. Salah satunya adalah kasus plagiarisme dari logo perguruan tinggi Institut Teknologi Sepuluh Nopember (ITS) yang berada di Surabaya oleh Inkom TehSnab, salah satu perusahaan yang berasal dari Rusia. Peristiwa ini menjadi suatu pemberitaan setelah banyak dibahas oleh para alumni ITS Surabaya. Tujuan peneliti membahas berbagai plagiarism yang dilakukan oleh perusahaan Inkom TehSnab dari sisi desain. Pada penelitian ini menggunakan metode kualitatif. Dalam pengumpulan data penelitiannya, peneliti menggunakan teknik pengumpulan data studi pustaka atau melalui berbagai dokumen yang ada. Sehingga dapat diketahui bahwa hasil dari analisis pihak perusahaan asal Rusia tersebut melakukan tipe plagiat total, yaitu sebesar $70 \%$.
\end{abstract}

Kata kunci: internet, logo, media, plagiarisme, desain

\begin{abstract}
The existence of the internet has more impacts, one of which is a negative impact. In the visual communication design industry, it is very possible that this happens, because it plays an important role in the process of finding ideas. One of them is the case of plagiarism from the logo of the Sepuluh November Institute of Technology (ITS) university in Surabaya by Inkom TehSnab, one of the companies from Russia. This event became a report after much discussion by ITS Surabaya alumni. The aim of the researcher is to discuss various plagiarism practices carried out by the Inkom TehSnab company in terms of design. In this research using qualitative methods. In collecting research data, researchers use literature study data collection techniques or through various existing documents. So it can be seen that the results of the analysis of the Russian company conducted a total plagiarism type, which is equal to $70 \%$.
\end{abstract}

Key word: internet, logos, media, plagiarism, design

\section{Pendahuluan}

\section{Latar Belakang}

Dewasa ini dalam kehidupan sehari-hari manusia banyak terjadi berbagai perkembangan atau pun perubahan. Di mana perkembangan atau pun perubahan tersebut terjadi dalam setiap sisi kehidupan manusia. Perkembangan atau pun perubahan yang terjadi tersebut terjadi dikarenakan adanya dampak dari Globalisasi. Globalisasi berasal dari kata globalization, yaitu "global: yang artinya dunia dan "lization" artinya proses (Welianto 2019). Dengan demikian, globalisasi adalah sebuah proses perkembangan atau pun perubahan yang terjadi dunia dalam hal ini dalam kehidupan manusia. 
Globalisasi terjadi karena berbagai sebab, salah satunya bidang teknologi informasi yang menyebar ke berbagai belahan dunia. Salah satu dampak dari globalisasi dalam ilmu pengetahuan adalah kemajuan teknologi yang berhasil membuat banyak inovasi di kehidupan sosial masyarakat. Globalisasi juga membuat kemajuan pada perkembangan media. Hal itu berkaitan dengan hadirnya internet. Internet merupakan sebuah dunia maya yang bersifat global yang dapat menembus ruang dan waktu, dalam arti lain internet mampu menjangkau wilayah-wilayah yang secara geografis berjauhan dalam waktu yang sama (Wardana and Husna 2017). Hadirnya internet sangat mempermudah banyak orang dalam segala hal, salah satunya dalam bidang informasi. Meskipun secara fisikteknologi internet merupakan wujud dari penggabungan jaringan berbagai komputer dunia, internet dapat dianggap sebagai gudang informasi. Sehingga, menjadikan internet sebagai salah satu sumber daya informasi yang sangat potensial untuk mempermudah sistem dalam kehidupan (Talika 2016).

Selain itu, dalam perkembangan sejarah teknologi komunikasi belum ada yang mampu untuk menandingi keberadaan internet dalam pertumbuhannya terlebih lagi jumlah penggunanya. Bahkan di beberapa negara maju, internet dapat mengalahkan media-media yang ada sebagai referensi dalam mencari atau pun mendapatkan informasi. Menurut Belch \& Belch (Morissan 2014) internet dapat didefinisikan sebagai sebuah sarana di seluruh dunia untuk bertukar informasi dan menjalin komunikasi melalui jaringan komputer yang saling terhubung. Oleh sebab itu, saat ini orang-orang yang mempunyai komputer dan modem dapat mengakses internet serta menjadi bagian dari jaringan komunikasi dunia.

Namun, semakin berkembangnya internet saat ini dapat menimbulkan banyak dampak negatif pagi para penggunanya. Termasuk dalam dunia industri DKV atau yang lebih dikenal dengan desain grafis. Tinarbuko di dalam bukunya mengungkapkan bahwa desain komunikasi visual (DKV) adalah konsentrasi ilmu yang membahas bentuk komunikasi dan ungkapan daya kreatif, kemudian dikembangkan dalam berbagai media komunikasi visual dengan mengolah berbagai elemen desain grafis terdiri dari gambar (ilustrasi), huruf, warna, komposisi dan layout (Tinarbuko 2015). Dalam hal ini, para desainer grafis dapat dengan mudah mengakses internet yang berfungsi untuk menambah informasi dalam pembuatan desain grafis (Wardana and Husna 2017). Hal tersebut pada saat desainer grafis mencari informasi terlebih dalam proses peracangan, maka dapat mengakibatkan terjadinya plagiat yang dilakukan dengan sengaja atau pun tanpa sengaja. Hal ini dikarena semua hasil karya desainer lain dapat dengan mudah untuk dimodifikasi atau pun ditiru tanpa harus meminta izin kepada pembuat desain aslinya. Soelistyo pada bukunya mengungkapkan bahwa plagiarisme atau plagiat merupan salah satu perbuatan menjiplak ide, gagasan, atau karya milik orang lain yang kemudian diakui sebagai karya sendiri atau dengan kata lain menggunakan karya punya orang lain namun tidak menyebutkan sumbernya sehingga menimbulkan asumsi yang salah atau keliru mengenai sumber utama dari suatu ide, gagasan atau karya (Budi 2011).

Sidharta menuliskan bahwa plagiarism dalam banyak hal dikatakan hanya sebagai pelanggaran etika, tapi bukan sebagai suatu perbuatan yang melanggar hukum. Dalam hal ini bahwa dalam Undang-Undang Nomor 28 Tahun 2014 telah tertulis dengan jelas bahwa hak cipta (copyright) adalah hak eksklusif pencipta yang timbul secara otomatis berdasarkan prinsip deklaratif setelah suatu ciptaan diwujudkan dalam bentuk nyata tanpa mengurangi pembatasan sesuai dengan ketentuan peraturan perundang-undangan (Sidharta 2015). Dengan demikian, hal tersebut sangat penting untuk dipahami para desainer grafis dalam industri desain komunikasi visual agar para desainer grafis terhindar dari berbagai kasus plagiarisme yang merugikan berbagai pihak yang terlibat di dalamnya. Selain itu, satu hal yang dapat menguatkan mudahnya terjadi perbuatan plagiat ini adalah dikarenakan ada suatu pernyataan dalam membuat desain yaitu amati, tiru, dan kembangkan.

Hal ini lah yang dialami oleh salah satu perguruan di Indonesia, yaitu Institut Teknologi Sepuluh Nopember (ITS) Surabaya. Terjadi plagiarism pada logo ITS Suarabaya yang dilakukan 
oleh Inkom TehSnab (ITS), sebuah perusahaan asal negara Rusia. Kejadian plagiarisme ini terjadi pada tahun 2012 dan menjadi perbincangan serius dikalangan sivitas akademi dan alumni ITS Surabaya. Berdasarkan pernyataan resmi dari perusahaan ITS Rusia, bahwa dalam pembuatan logo perusahaannya memesan dari suatu perusahaan jasa desain yang di mana perusahaan jasa desain tersebut tidak dapat dihubungi kembali untuk dilakukan konfirmasi (Dadang 2012). Pada akhirnya perusahaan InkomTehSnab (ITS) dari Rusia mengakui kesalahan dan menyampaikan permintaan maaf terhadap peristiwa yang terjadi.

Dengan begitu, dalam hal ini peneliti akan membahas kasus plagiarisme pada logo ITS (Institut Teknologi Sepuluh Nopember), Surabaya, Indonesia yang diakukan oleh ITS (Inkom TehSnab), sebuah perusahaan yang berasal dari Rusia. Dalam kasus ini, perusahaan Rusia tersebut melakukan plagiarisme pada bagian logo perguruan tinggi ITS Surabaya. Hal ini mengingat bahwa logo merupakan bagian terpenting dari suatu instansi atau sebuah perusahaan, karena logo merupakan tanda-tanda, berbagai lambang, ataupun simbol yang memiliki arti dan digunakan sebagai penunjuk identitas sebuah organisasi, perusahaan atau individu agar mudah diingat oleh orang lain (Ledewyk Sagala 2013). Pembahasan kasus plagiarisme yang dilakukan oleh peneliti berdasarkan dari sudut pandang desain.

Teori

Plagiarisme

Plagiarisme atau plagiat adalah suatu perilaku meniru ide, gagasan, atau hasil karya orang lain yang selanjutnya diakui sebagai karya pribadi atau dengan kata lain menggunakan karya orang lain namun tidak menyebutkan sumbernya sehingga menimbulkan asumsi yang salah atau keliru mengenai asal muasal dari suatu ide, gagasan atau karya (Budi 2011). Plagiarisme sederhananya adalah melakukan copy dan paste dari produk intelektual orang lain yang disalahgunakan tanpa menyebutkan nama penulis, penemu, dan penggagas orisinal (Shadiqi).

Soelistyo di dalam bukunya menyampaikan bahwa plagiarisme atau plagiat dapat diklasifikasikan dalam beberapa tipe, yaitu (Budi 2011):

1. Plagiat Ringan, jumlah plagiat kurang dari $30 \%$.

2. Plagiat Sedang, jumlah plagiat $30 \%-70 \%$.

3. Plagiat Total, jumlah plagiat lebih dari $70 \%$.

Desain

Dalam membuat suatu desain, maka seorang desainer perlu memperhatikan unsur-unsur desain di dalamnya. Said mengungkapkan bahwa unsur-unsur desain, yaitu (Said, 2006):

1. Titik

Titik sebagai menandai sebuah tempat. Titik tidak memiliki panjang dan lebar, merupakan pangkal dan ujung sepotong garis, dan merupakan perpotongan atau pertemuan antara dua garis.

2. Garis

Garis adalah titik-titik yang saling bersambung satu dengan lainnya. Garis yang merupakan deretan-deretan titik tersebut memiliki sifat konsep. Garis merupakan bagian luar dan batas sebuah bidang, tempat dua bidang bersambungan, juga tempat dua bidang berpotongan.

3. Bidang

Bidang merupakan suatu jalur yang dilalui oleh sepotong garis, yang bergerak membentuk sebuah bidang yang dibatasi garis. Bidang adalah batas paling luar dari sebuah benda.

4. Bentuk

Bentuk merupakan semua unsur rupa yang tersusun. Hal inilah yang menjadi perhatian utama kita dalm mempelajari bahasa. Bentuk yang dimaksudkan disini bukanlah raut yang polos, melainkan raut yang memiliki ukuran, warna, dan barik tertentu. 


\section{Warna}

Warna merupakan sebuah kesan yang ditimbulkan oleh cahaya pada mata. Berbagai warna yang dapat ditangkap oleh mata normal hanya berkisar pada spectrum dari warna merah sampai dengan ungu, sedang antara spectrum warna infra red (infra merah) ke atas dan ultraviolet (ultra-ungu) ke bawah hanya dapat dilihat dengan menggunakan peralatan khusus.

Dalam penulisan artikel ini, peneliti akan menjelaskan letak plagiarisme yang dilakukan oleh Inkom TehSnab salah satu perusahaan asal Rusia berdasarkan unsur-unsur desain.

Layout

Layout atau tata letak dapat diartikan sebagai suatu tata letak berbagai elemen desain terhadap suatu bidang. Me-layout adalah suatu proses kerja dalam mendesain. Dengan kata lain, bahwa desain merupakan arsiteknya, sedangkan layout pekerjanya. Namun, pengertian sesungguhnya dari layout dalam perkembangannya sudah banyak, dan melebur dengan definisi desain itu sendiri. Sehingga banyak yang mengatakan bahwa me-layout sama dengan mendesain (Rustan 2009). Selain itu, tata letak atau layout memiliki tujuan untuk menciptakan suatu tampilan visual yang memuaskan, menstimulasi, menggugah pikiran, dan nyaman magi mata (Klimchuk and Krasovec 2007).

Logo

Logo dapat memberikan arti tertentu dan menandakan asal, kepemilikan, atau asosiasi. Logo dapat berupa (Sari 2017):

1. nama korporasi atau tanda dagang (tanda berupa kata dengan hanya teks) yang ditulis dalambentuk yang khusus.

2. rancangan abstrak yang secara lengkap tidak berhubungan dengan tanda kata, nama perusahaan, atau aktivitas perusahaan (non-word mark logos ini disebut juga simbol).

Dalam proses pembuatan suatu logo perlu terdapat tiga elemen penting yang harus diperhatikan, yaitu (Iskandar 2007):

1. nama, kaitannya dengan kata atau bunyi.

2. simbol, kaitannya dengan bentuk tampilan visual.

3. Warna, harus memiliki daya tarik, makna simbolik, dan juga berpengarus pada sisi psikologis.

Oleh sebab itu, yang penting untuk identifikasi brand atau perusahaan, adalah desain yang menarik karena ia menggunakan tipografi, ilustrasi, dan layout untuk menghasilkan gambar yang unik, berbeda serta mudah diingat yang bagi mengidentifikasi brand (Moriarty, Mitchell, and Wells 2011).

Di dalam merancang suatu logo terdapat dua istilah, yang pertama logotype yaitu logo yang hanya terdiri dari elemen tulisan. Hal ini dikarenakan dalam teknik pembuatannyannya berupa lettering atau hanya menggunakan jenis huruf (font) tertuntu. Yang kedua logogram adalah bentuk sederhana atau simbol yang mewakili sebuah makna, seperti ' $\&$ " yang dibaca dan. ' 1 ' yang kit abaca satu (Redono 2013). Berkembangnya kebutuhan, semakin banyak yang menggabungkan logotype dan logogram menjadi seuatu logo yang dapat dikenal dan diingat masyarakat.

Dalam hal ini, jenis logo yang terkandung dalam logo ITS adalah perpaduan antara logotype dan logogram. Logotype merupakan bentuk logo yang terdiri dari rangkaian huruf dari nama perguruan tinggi, sedangkan logogram adalah logo yang terdiri dari gambar atau simbol yang menggambarkan atau mendeskripsikan suatu simbol, ikon, dan sebagainya.

Pada saat proses membuat logo, terjadi perubahan bentuk supaya sesuai dengan kebutuhan akan logo tersebut. Menurut Chandra (2012), perubahan bentuk tersebut, yaitu:

1. Stilasi. Stilasi merupakan perubahan bentuk dalam mencapai suatu bentuk keindahan dengan menggayakan objek yang digambar. 
2. Distorsi. Distorsi merupakan proses penggambaran bentuk yang berfokus pada pencapaian suatu karakter dengan memperkuat wujud-wujud tertentu pada benda atau objek yang digambar.

3. Transformasi. Transformasi merupakan proses menggambar bentuk yang menitikberatkan pada pencapaian karakter dengan memindahkan wujud atau figur dari objek lain ke objek yang digambar.

4. Deformasi. Deformasi merupakan penggambaran bentuk yang memfokuskan pada penginterpretasian karakter melalui mengubah bentuk objek yang dapat mewakili atau pengambilan unsur tertentu yang mewakili karakter hasil interpretasi yang sifatnya sangat hakiki.

\section{Ilustrasi}

Ilustrasi berasal dari bahasa Latin yakni illustrate, yang memiliki arti menerangi atau memurnikan. Sehingga llustrasi merupakan suatu penggambaran yang dirancang untuk dapat membuat lebih jelas sebuah informasi dengan memberi representasi secara visual. Sehingga utama dari suatu ilustrasi adalah suatu pemikiran, ide serta konsep yang menjadi landasan apa yang ingin dikomunikasikan oleh gambar (Witabora 2012).

Ilustrasi memiliki fungsi yang terbagi menjadi dua, yakni secara khusus dan umum yang dijabarkan sebagai berikut (seputarpengetahuan 2017):

1. fungsi dari ilustrasi secara khusus, yakni:

a. Memberikan bayangan masing-masing karakter dalam cerita.

b. Memberikan bayangan rupa alat-alat yang dipakai dalam tulisan ilmiah.

c. Memberikan bayangan langkah kerja.

d. Saluran komunikasi cerita.

e. Menjadi penghubung antara tulisan dengan kreativitas dan individualitas manusia.

f. Memberikan humor-humor tertentu untuk mengurangi rasa bosan.

g. Bisa menerangkan konsep yang disampaikan

2. Fungsi ilustrasi secara umum, yakni:

a. Fungsi Deskriptif

Fungsi deskriptif ilustrasi adalah sebagai pengganti uraian terhadap suatu secara verbal dan naratif dengan mengguakan kalimat panjang. Ilustrasi bisa digunakan untuk melukiskan sehingga dapat lebih cepat dan lebih mudah untuk dipahami.

b. Fungsi Ekspresif

Fungsi ekspresif ilustrasi adalah menunjukkan dan menyatakan suatu gagasan, perasan, maksud, situasi ataupun konsep yang abstrak secara nyata sehingga lebih mudah dipahami.

c. Fungsi Analitis atau Struktura

Fungsi analitis ilustrasi yaitu ilustrasi bisa memperlihatkan secara rinci bagian demi bagian dari suatu benda maupun sistem atau proses dengan detail, untuk lebih mudah dipahami

d. Fungsi Kualitatif

Fungsi kualitatif biasanya digunakan ketika dalam pembuatan daftar, tabel, grafik, kartun, foto, gambar, sketsa dan simbol.

Adapun berbagai jenis dari ilustrasi, adalah sebagai berikut:

1. Gambar Ilustrasi Naturalis

Gambar ilustrasi naturalis merupakan gambar ilustrasi yang mempunyai bentuk dan warna yang sama dengan wujud nyata yang ada pada alam tanpa terdapat pengurangan ataupun penambahan. 
2. Gambar llustrasi Dekoratif

Gambar ilustrasi dekoratif merupakan gambar yang fungsinya untuk menghiasi sesuatu dengan bentuk yang disederhanakan atau dilebihkan dengan gaya tertentu.

3. Gambar Kartun

Gambar kartun merupakan gambar yang mempunyai bentuk lucu ataupun mempunyai ciri khas tertentu. Seringkali gambar kartun lebih banyak menghiasi majalah anak-anak, komik dan juga certa bergambar.

4. Gambar Karikatur

Gambar karikatur merupakan gambar kritikan atau sindiran yang dalam perwujudtannya sudah terjadi penyimpanan proporsi tubuh. Gambar ini bisa ditemukan di majalah atau Koran.

5. Cerita Bergambar

Cerita bergambar (Cergam) adalah sejenis komik atau gambar yang diberi teks. Teknik gambar yang dibuat berdasarkan cerita dengan sudut pandang yang menarik.

6. Ilustrasi Buku Pelajaran

Ilustrasi buku pelajaran fungsinya untuk menjelaskan teks ataupun suatu kejadian baik yang ilmiah ataupun berupa gambar bagian. Dapat berupa foto, gambar natural, dan juga dapat berbentuk bagan.

7. Ilustrasi Khayalan

Ilustrasi khayalan adalah gambar hasil olahan daya cipta dengan imajinatif (khayal). Cara menyatakannya seperti yang bisa ditemukan pada ilustrasi cerita, novel, komik dan juga roman

\section{Metode}

Metode dalam penulisan artikel ini adalah metode penelitian kualitatif. Bogdan dalam Saeful (2009) menjelaskan bahwa metode penelitian kualitatif adalah suatu prosedur penelitian yang dapat menghasilkan data secara deskriptif berupa ucapan atau pun tulisan dan perilaku orang-orang yang diamati. Menurut Sugiyono dalam bukunya, bahwa metode kualitatif dapat terjadi tiga kemungkinan terhadap "masalah" dalam penelitian, yang pertama "masalah" yang dibawa oleh peneliti tidak mengalami perubahan hingga akhir penelitian. Yang kedua "masalah" yang dibawa peneliti mengalami perluasan atau lebih mendalam dari permasalahan yang telah disiapkan. Yang ketiga "masalah" yang dibawa peneliti mengalamai perubahan atau berganti masalah setelah proses penelitian sedang berlangsung (Sugiyono 2018).

Menurut Anggito dan Setiawan, pada penelitian kualitatif terdapat tiga teknik utama dalam pengumpulan data, yaitu dengan observasi lapangan, wawancara terhadap narasumber, dan studi pustaka (Limbong et al. 2019). Sugiyono menuturkan bahwa observasi adalah dasar semua ilmu pengetahuan, karena observasi merupakan fakta mengenai dunia kenyataan yang diperoleh dari lapangan. Selain itu, teknik pengumpulan data melalui wawancara apabila peneliti ingin melakukan studi pendahuluan untuk memnemukan permasalahan atau pun mengetahui hal-hal dari responden yang lebih mendalam. Terakhir studir pustaka berbentuk tulisan, gambar, atau karya-karya monumental dari seseorang (Sugiyono 2018).

Dapat disimpulkan bahwa teknik analisis yang peneliti menggunakan metode kualitatif yang bersifat deskriptif. Selain itu, dalam penulisan ini masalah pada penelitian ini adalah tetap yang dimulai sejak awal penelitian. Dalam pengumpulan data, peneliti menggunakan teknik pengumpulan data studi pustaka yaitu mengumpulkan dan menganalisis berbagai artikel berita dari berbagai sumber yang berkaitan dengan plagiarisme logo ITS Surabaya. Peneliti juga menggunakan website Institut Teknologi Sepuluh Nopember (ITS) Surabaya sebagai sumber data 
dalam penelitian. Sehingga peneliti dapat mengetahui informasi lebih luas dan lengkap mengenai objek yang akan diteliti secara mendalam. Objek penelitian yang akan dibahas dalam penulisan ini adalah logo Intitut Teknologi Sepuluh Nopember (ITS), Surabaya, Indonesia yang diplagiat oleh Inkom TehSnab salah satu perusahaan yang berasal dari negara Rusia. Kemudian, teknik pengumpulan data yang peneliti gunakan yaitu mengumpulkan dan menganalisis berbagai artikel berita dari berbagai sumber yang berkaitan dengan pembajakan logo ITS. Peneliti juga menggunakan website Institut Teknologi Sepuluh Nopember (ITS) sebagai sumber data dalam penelitian.

\section{Hasil dan Pembahasan}

\section{Makna Lambang dan Logo Institut Teknologi Sepuluh Nopember (ITS) Surabaya}

Berdasarkan Peraturan Menteri Pendidikan dan Kebudayaan Republik Indonesia Nomor 49 Tahun 2011 tentang Statuta Institut Teknologi Sepuluh Nopember, ITS memiliki lambang dan logo. Lambang ITS dipergunakan untuk kepentingan internal kampus ITS. Makna lambang yang dimaksud, sebagai berikut:

1. Roda teknik berwarna biru tua dan biru muda mengandung makna perjuangan kepahlawanan bangsa yang suci menjamin harapan kepada kader bangsa yang berbudi pekerti luhur di dalam ilmu pengetahuan, teknologi, dan seni.

2. Tugu Pahlawan Surabaya berwarna putih perak mengandung makna semangat kepahlawanan Sepuluh Nopember.

3. Bunga Wijaya Kusuma berwarna kuning ema mengandung makna lambang kehidupan.

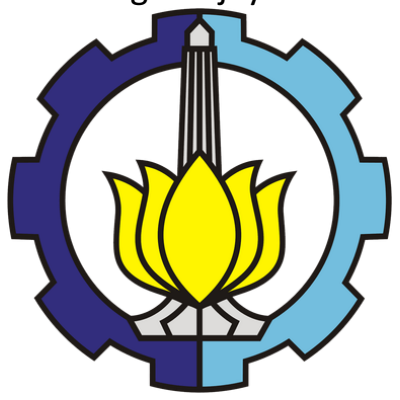

Gambar 1 Lambang Institut Teknologi Sepuluh Maret (ITS) Surabaya Sumber: ("Lambang dan Logo ITS")

Pada desain logo ITS terdiri dari unsur-unsur yang memiliki makna. Logo dari ITS ini digunakan untuk kepentingan eksternal. Berikut ini makna-makna dari logo ITS Surabaya, sebagai beriku:

1. Lambang ITS berwarna putih di dalam perisai, mengandung makna semangat membangun kompetensi generasi muda dalam bidang ilmu pengetahuan, teknologi, dan seni agar selalu tertanan dan terbingkai di dalam hati seluruh sivitas akademika dan tenaga kependidikan.

2. Tulisan "ITS" berwarna biru mengandung makna visi ITS seluas dan setinggi langit lazuardi dan selalu dapat beradaptasi dengan perubahan

3. Tulisan "ITS" berbentuk tegas, artistik dan sederhana, dan mengandung makna pengalaman dalam bidang ilmu pengetahuan, teknologi, dan seni, kekuatan sejarah, dan senioritas ITS semakin mempunyai daya saing. 


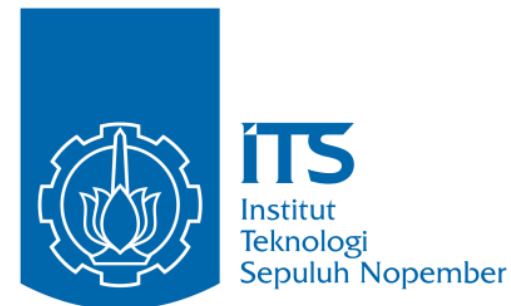

Gambar 2 Logo Institut Teknologi Sepuluh Maret (ITS) Surabaya Sumber: ("Lambang dan Logo ITS")

Bila diamati dengan seksama, lambang dan logo yang dimiliki oleh Institut Teknologi Sepuluh Nopember (ITS) Surabaya memiliki perubahan bentuk stilasi. Hal ini dikarenakan terdapat dalam desain lambang dan logo tersebut hampai menyerupai dengan bentuk aslinya, yakni Roda, Tugu Pahlawan Surabaya, dan Bunga Wijaya Kusuma. Dalam melakukan illustrasi terhadap lambang dan logo dari ITS Surabaya ini, sebagai fungsi ekspresih di mana dalam setiap bentuknya menggambarkan suatu gagasan, perasaan, makna.

Di sisi lain, apabila diperhatikan lambang dan logo ITS Surabaya dibuat dengan gaya ilustrasi naturalis yang di mana bentuknya sama dengan wujud nyata. Dengan demikian lambang dan logo yang dimiliki oleh ITS Surabaya akan mudah dipahami secara desain.

Analisis Plagiarisme Logo Institut Teknologi Sepuluh Nopember (ITS) Surabaya oleh Inkom TehSnab (ITS) Rusia
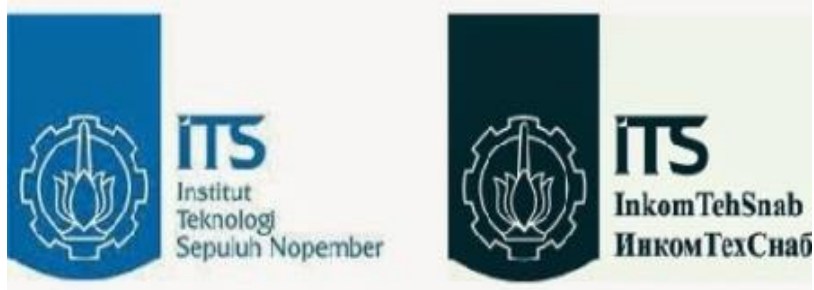

Gambar 3 Logo ITS Asli (Kiri) Logo ITS Plagiarisme (Kanan) Sumber: (detikInet 2012)

Peristiwa plagiarisme yang dilakukan oleh perusahaan asal negara Rusia bernama Inkom TehSnab (ITS) terjadi pada tahun 2012. Peristiwa plagiarism muncul dalam pemberitaan setelah ramai dibahas oleh para alumni ITS Surabaya (Dadang 2012). Setelah itu pihak berwenang dari ITS Surabaya melakukan tindak lanjut terhadap hal tersebut. Bila diamati, kedua logo tersebut memiliki kesamaan. Oleh sebab itu, peneliti memaparkan hasil dari berbagai hal yang telah di plagiat oleh perusahaan asal Rusia tersebut dari sisi desain, sebagai berikut: 


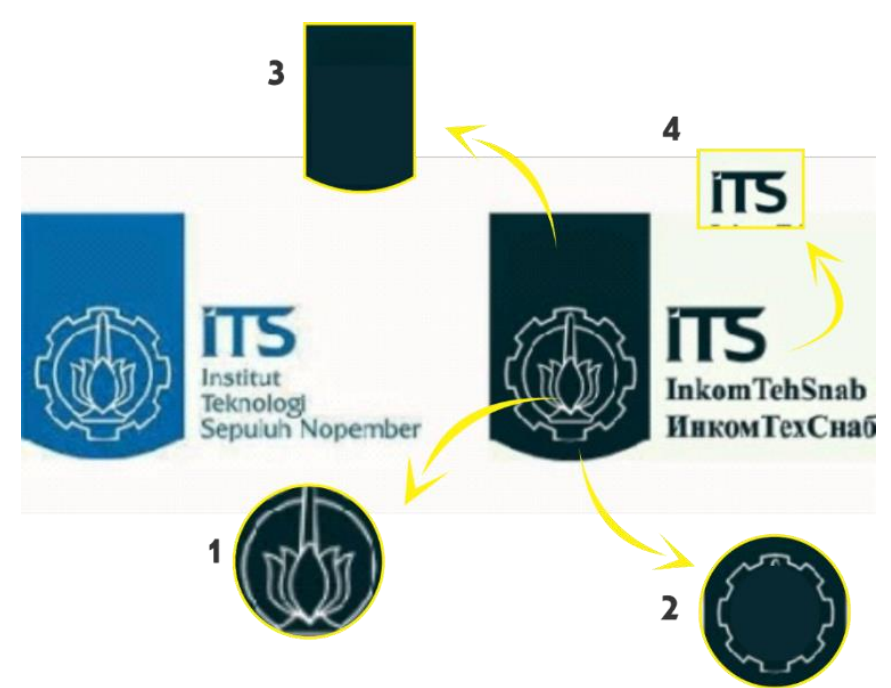

Gambar 4 Letak Plagiarisme Pada Logo ITS Rusia

Sumber: Dokumen pribadi

Dalam kasus ini, plagiarisme yang dilakukan oleh perusahaan Rusia yaitu Inkom TehSnab (ITS) termasuk ke dalam klasifikasi plagiarisme tipe plagiat total, yaitu dimana jumlah plagiat yang dilakukan oleh perusahaan asal Rusia tersebut lebih dari $70 \%$. Hal ini dikuatkan dengan berbagai bentuk yang dikaitkan dengan teori yang telah dijelaskan sebelumnya, yaitu sebagai berikut:

1. Ditinjau dari kemiripan bentuk lambang.

Adapun lambang-lambang ITS Surabaya yang diplagiat oleh perusahaan Rusia terdiri dari bentuk Roda Teknik yang terdapat pada nomor dua. Kemudian lambang yang di plagiat adalah Tugu Pahlawan dan Bunga Wijaya Kusuma yang dapat dilihat pada gambar kesatu. Dalam hal ini sangat terlihat jelas dalam plagiat yang dilakukan oleh perusahaan ITS Rusia sama persis hingga detail dari bentuknya pun tidak ada yang berbeda.

2. Ditinjau dari warna latar belakang

Apabila dilihat dengan seksama, penggunaan warna latar belakang yang terdapat pada logo perusahaan ITS Rusia hampir menyerupai dengan warna belakang yang dimiliki oleh ITS Surabaya yakni sama-sama berwarna biru. Akan tetapi masih terdapat perbedaan, yaitu latar belakang yang terdapat pada logo ITS Surabaya berwarna biru muda dan lebih terang, sedangkan pada latar belakang yang tercantum pada logo peruhaan ITS Rusia memiliki warna biru tua dan lebih gelap. Hal tersebut dapat dilihat pada gambar ketiga.

3. Ditinjau dari bentuk Logo

Berikutnya bila ditinjau dari kesamaan logo yang dimiliki oleh perusahaan ITS asal Rusia. Hal plagiat yang dilkukan dalam bentuk perisai yang terdapat pada gambar ketiga. Secara ukuran memiliki persamaan. Selain itu, hal plagiat yang dilakukan oleh ITS Rusia adalah tulisan singkatan ITS yang memiliki kesamaan bentuk dan ukuran. Ada sedikit perbedaan dalam hal ketebalan huruf pada logo perusahaan ITS Rusia lebih tebal dibanding dengan logo ITS Surabaya. Selain itu bila ditinjau dari bentuk logo, plagiat lainnya yakni terjadi persamaan pada tulisan singkatan dari ITS.

Selain hal-hal yang telah dipaparkan bagian sebelumnya, bukti plagiarisme juga dapat ditemukan dalam tata letak (layout) logo yang dibuat peneliti. Agar dapat terlihat lebih detail plagiarism dari logo perusahaan ITS Rusia terhadap perguruan tinggi ITS Surabaya, kami tampilkan layout dari kedua logonya, sebagai berikut: 


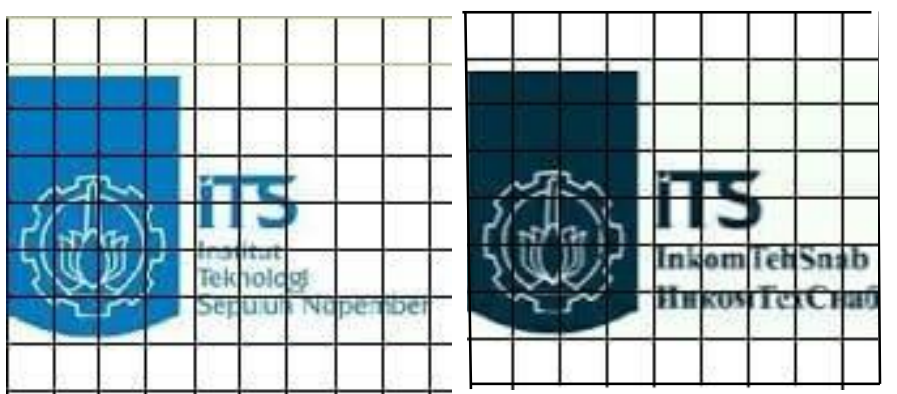

Gambar 4 Grid Logo ITS Surabaya (Kiri) Grid Logo ITS Rusia (Kanan) Sumber: Dokumen Pribadi

Dari gambar di atas terbukti bahwa logo Inkom TehSnab benar-benar melakukan plagiat logo ITS Surabaya, karena letak penempatan desainnya yang sudah peneliti buat dalam grid sama persis, yang membedakan hanyalah penempatan tulisan Inkom TehSnab dalam bahasa Rusia yang lebih besar ukuran typeface-nya dibanding tulisan Institut Teknologi Sepuluh Nopember. Selain itu, dari setiap sisi ruang kosong tidak memiliki perbedaan antara logo yang dimiliki oleh perusahaan Inkom TehSnab asal Rusia dengan logo yang yang dimiliki oleh Institusi Teknologi Sepuluh Nopember (ITS) Surabaya.

\section{Tindak Lanjut Institut Teknologi Sepuluh Nopember (ITS) Surabaya dan Perusahaan Inkom} TehSnab Rusia

Diakses dari situs Its.ac.id bahwa apa yang dilakukan oleh Inkom TehSnab benar adanya, dan Institut Teknologi Sepuluh Nopember membawa masalah ke jalur hukum, jika Inkom TehSnab tersebut tidak mengganti logo tersebut. Pihak dari perguruan tinggi Institut Teknologi Sepuluh Nopember (ITS) Surabaya mengirimkan surat kepada pihak perusahaan Inkom TehSnab yang ada di Rusia sebagai langkah tegas dari pihak ITS Surabaya.

Pada akhirnya perusahaan Rusia tersebut mengakui kesalahannya atas kasus plagiarisme yang dilakukan oleh perusahaan tersebut. Mereka mengakui bahwa pihak perusahaan menggunakan perusahaan jasa desain untuk mendesain logo perusahaan mereka. Setelah pihak perguruan tinggi ITS melaporkan kejadian ini ke perusahaan ITS di Rusia, dalam dua minggu pun perusahaan ITS di Rusia telah mengganti dengan logo perusahaan yang baru.

\section{Simpulan}

Berdasarkan hasil penelitian yang telah dilakukan oleh peneliti dalam penulisan ini, dapat disimpulkan bahwa dengan perkembangan pada teknologi informasi dan komunikasi sangat membantu dalam mencari data yang dibutuhkan. Karena semua dapat terhubung secara global. Pada sisi lain, perkembang teknologi informasi tersebut memberikan dampak negatif pula bagi penggunanya. Terlebih dalam bidang desain grafis. Para desainer dapat dengan mudah untuk mencari gambar yang sangat memungkinkan terjadinya kasus-kasus plagiat. Hal inilah yang terjadi pada perusahaan asal Rusia, yakni Inkom TehSnab (ITS) yang melakukan plagiat terhadap logo yang dimiliki oleh perguruan tinggi Institut Teknologi Sepuluh Nopember (ITS) Surabaya. Dari sisi desain didapatkan bahwa pihak perusahaan ITS melakukan tipe plagiat total yang meliputi sisi layout hingga lambang-lambang.

Oleh sebab, sebagai desainer sebaiknya melihat karya milik orang lain hanya sebatas untuk menambah ide saja, dalam proses pembuatan desainnya lebih baik gunakan imajinasi atau ide sendiri yang berbeda. Kemudia, penting dilakukan bagi pihak mana pun untuk 
mendaftarkan hak cipta terdapat desainnya sehingga mendapatkan perlindungan hukum apabila terjadi kasus plagiarism atau plagiat.

\section{Daftar Pustaka}

Budi, Henry Soelistyo. 2011. Plagiarisme: Pelanggaran Hak Cipta dan Etika. Yogyakarta: Kanisius.

Chandra, Tony Van. 2012. "Tinjauan elemen visual pada logo baru PT.Kereta Api Indonesia (persero) dan keselarasannya dengan budaya perusahaan." Sarjana Tugas Akhir, Desain Komunikasi Visual Fakultas Desain, Universitas Komputer Indonesia. https://elib.unikom.ac.id/gdl.php?mod=browse\&op=read\&id=ibptunikompp-gdltonyvancha-28556\&q=tony.

Dadang. 2012. "Terbukti, Logo ITS Asli Punya ITS." Institut Teknologi Sepuluh Nopember. Accessed March 18. https://www.its.ac.id/news/2012/03/26/terbukti-logo-its-aslipunya-its/.

detikInet. 2012. "Jiplak Logo ITS, Perusahaan Rusia Shock." detik.com, 2012. Accessed March 18, 2020. https://inet.detik.com/cyberlife/d-1856699/jiplak-logo-its-perusahaan-rusiashock?device=desktop\&device=desktop.

Iskandar, Syahril. 2007. Aplikasi Periklanan Menggunakan Corel Draw X3. Jakarta: Elex Media Komputindo.

Klimchuk, Marianne Rosner, and Sandra A Krasovec. 2007. Desain kemasan: Perencanaan merek produk yang berhasil mulai dari konsep sampai penjualan. Jakarta: Penerbit Erlangga.

"Lambang dan Logo ITS." Institut Teknologi Sepuluh Nopember. Accessed March 19. https://www.its.ac.id/id/tentang-its/profil-singkat/logo-its-2/.

Ledewyk Sagala, Andreas. 2013. "Tinjauan histori logo PT. Telkom Indonesia Tbk." Sarjana Tugas Akhir, Desain Komunikasi Visual Fakultas Desain, Universitas Komputer Indonesia. https://repository.unikom.ac.id/25564/.

Limbong, Edo Galasro, Ismail Bambang Subianto, Friza Youlinda Parwis, and Prin Suprianto. 2019. "Perancangan Ilustrasi Tata Cara Penggunaan Kendaraan Umum sebagai Media Edukasi." SAP (Susunan Artikel Pendidikan) 4 (1): 1-8. https://doi.org/10.30998/sap.v4i1.3892.

Moriarty, Sandra, Nancy Mitchell, and William Wells. 2011. Advertising kedelapan ed. Jakarta: Kencana Prenada Media Group.

Morissan. 2014. Periklanan: Komunikasi Pemasaran Terpadu. Jakarta: Penerbit Kencana.

Redono, Daru. 2013. Simple Promotion dan Branding untuk UKM. Malang: Universitas Brawijaya Press.

Rustan, Surianto. 2009. Layout dasar dan penerapannya. Jakarta: Gramedia.

Saeful, Rahmat Pupu. 2009. "Penelitian Kualitatif." Equilibrium 5 (9): 1-8. 
Sari, Christina Ariadne Sekar. 2017. Teknik Mengelola Produk dan Merek. Jakarta: Gramedia Pustaka Utama.

seputarpengetahuan. 2017. "Pengertian Ilustrasi, Fungsi, Tujuan, Jenis, Teknik, Contoh Terlengkap." Portal Media Pengetahuan Online Seputar Pengetahuan (blog), Seputar Pengetahuan. January 28. https://www.seputarpengetahuan.co.id/2017/09/pengertian-ilustrasi-fungsi-tujuanjenis-teknikcontoh.htm|\#: :text=Tujuan\%20dari\%20ilustrasi\%20yaitu\%20untuk,puisi\%2C\%20atau \%20informasi\%20tertulis\%20lainnya.\&text=Untuk\%20menjelaskan\%20pesan\%20atau \%20informasi,mudah\%20pembaca\%20untuk\%20memahami\%20pesan.

Shadiqi, Muhammad Abdan. "Memahami dan Mencegah Perilaku Plagiarisme dalam Menulis $\begin{array}{llllll}\text { Karya } \quad \text { Ilmiah." } & \text { Buletin }\end{array}$ https://doi.org/10.22146/buletinpsikologi.43058.

Sidharta. 2015. Plagiarisme: Pelanggaran Hak Cipta (Bagian 3 Dari 3 Tulisan).

Sugiyono. 2018. Metode Penelitian Kuantitatif, Kualitatif, dan R\&D. Bandung: Alfabeta.

Talika, Febi Trafena. 2016. "Manfaat Internet Sebagai Media Komunikasi Bagi Remaja Di Desa Air Mangga Kecamatan Laiwui Kabupaten Halmahera Selatan." ACTA DIURNA KOMUNIKASI 5 https://ejournal.unsrat.ac.id/index.php/actadiurnakomunikasi/article/view/10933.

Tinarbuko, Isidorus Tyas Sumbo. 2015. DEKAVE: Desain Komunikasi Visual Penanda Zaman Masyarakat Global. Yogyakarta: CAPS.

Wardana, Oki Dwi, and Jazimatul Husna. 2017. "Pemanfaatan Internet dalam Pembuatan Desain Grafis Di Kampung Desain Komunitas Rewo-Rewo (Studi Kuantitatif Di Desa Kaliabu, Kecamatan Salaman, Kabupaten Magelang)." Jurnal Ilmu Perpustakaan 6 (1): 321-330. https://ejournal3.undip.ac.id/index.php/iip/article/view/23090.

Welianto, Ari. 2019. "Globalisasi: Arti dan Dampaknya." kompas.com, 20 Desember, 2019. Accessed $18 \quad$ Maret 2020. https://www.kompas.com/skola/read/2019/12/20/100000969/globalisasi-arti-dandampaknya?page=all.

Witabora, Joneta. 2012. "Peran dan perkembangan ilustrasi." Humaniora 3 (2): 659-667. https://doi.org/10.21512/humaniora.v3i2.3410. 